\title{
Blurring Human and Machine Boundary --The Post-Humanist Metaphor of Cyborg-Body in Artificial Intelligence and Minority Report
}

\author{
Dongyang Li \\ Department of Gender and Cultural Studies, University of Sydney, Sydney, NSW, 2016, Australia \\ Corresponding author's e-mail: angela@cas-harbour.org
}

\begin{abstract}
Cyborg, also known as e-bio human, is a body type with mechanical/digital transformation as its representation, which was born out of the cyberpunk subculture. This paper aims to make a detailed comparative study of two opposite types of the cyber body in films Artificial Intelligence(Steven Spielberg 2001) and Minority Report(Steven Spielberg 2002), so as to reveal how cyborg body blurs the boundary between body and machinery, and impacts people's cognition of the body from the philosophical issues on the dualism of body and mind. In terms of methodology, the image analysis and critical discourse analysis are used to explore the problematic metaphor symbolized by cyborg body. Besides, the body study approach in cultural study is utilized to focus on the significance of cyborg cultural philosophy. In conclusion, it is argued that the cyborg body transcends the boundary between the human body and the mechanical body, as well as the dualistic opposition of the body and mind, thus bringing the cognition of the human body into a post-human era, that is, an era that needs to renegotiate the definition and boundary of humans and technology.
\end{abstract}

Keywords: Cyborg, body-mind-dualism, human-machine-boundary, post-humanism, human identification.

\section{INTRODUCTION}

In two Spielberg's cyberpunk films, namely, Minority Report and Artificial Intelligence, the director presents us with two different types of human-machine hybrids - one is the digitally transformed human body, and the other is the mechanical body transformed into the human body. These two contradictory but closely relevant problematic bodies uncomfortably blur the boundary between the human body and the machinery body, thus triggering a post-humanist debate about how to redefine the cyborg body and how to draw a clear line between human and machine. That is, in today's gradual integration of human body and robot body, how to redefine the definition of human beings, or how to negotiate novel boundaries between human and mechanical bodies?

At the end of Minority Report, the trajectory of the camera slowly pulls out of the house until it floats over an island crisscrossed by a river. watching Agatha alone with a silent gaze, what appears in front of the audience is an isolated island hut, which looks like a separate prison. To imprison Agatha out of the human world forever. Some people think that the last scene is not so much a symbol of Agatha's freedom as a complete, eternal alienation[1]. However, a new controversial issue arises: why Agatha is still regarded as an "alien" after she regained her human identity and removed all her digital-machinery equipment? The final scene of the film is open-ended, and Agatha is partially recognized as a human being and gets her human life, but no one knows whether the space she exists will be forever isolated from the human world or not. It can be said that the film does not provide a final answer to reassure the definition of human and machinery, which leads to the research question of this paper: if cyborg's body always blurs the boundary between human and machinery, how to perceive cyborg's hybrid body and the body-mind dualistic debate caused by it?

\section{BLURRED BOUNDARY: HUMAN- MACHINE BINARY AND CYBORG BODY}

Given that people noticed that Agatha's body had a gift for predicting the future, they digitally transformed her body, namely, through digital technology to intensify the body's potential to create a human-machine hybrid prophet's body, as shown in fig 1. Although Agatha's body originally has the general characteristics of all human bodies, or she seems to be just an ordinary human being, she seems to have become a "monster" of half-human and half-machine, when her body underwent digital transformation, immersed in the nutrient, and connected with a giant machine by several cables. At this point, Agatha's body become questionable: it belongs neither to the human body category nor to the mechanical body category, while her body is closer to a "cyborg" state. Here, "cyborg", as an amalgam of cybernetics and organism, effectively evokes the defining features of the term: the integration of digital, mechanical or cyborg components with biology[2]. However, the mechanical state showcased in Agatha's body is not 
inseparable from the body. Mechanical technology is only a technical means used to increase the function of her body. It can be said that Agatha's body can only be regarded as an unfinished cyborg body. Despite that, it is the vagueness and instability of Agatha's body that makes her rejected by the human world. For example, Agatha's residence is called a "temple", which means an inhuman place. Agatha's body is described as "better not to be treated as a human body". From people's attitude towards Agatha's body, It can be seen that the combination of mechanical technology and physical body has completely changed the way people perceive her body. Specifically, Agatha's human features (such as ordinary flesh and normal facial features, etc) are ignored. Simultaneously, her humanity is eliminated and replaced by "alien" or "the otherness". From this perspective, mechanical technology eventually leads to the dehumanization of Noumenon by blurring and distorting the body and the way in which the body is perceived by people. A post-humanist chimera that is composed of human and non-human, in its representation, causes the ambiguity and instability of human body, thus forming a semiotic fear and arousing unsetting association[3]. Thus, the post-human hybrid of human and non-human is habitually imagined as a discordant combination of fear and destruction. In light of this theory, the clues of people's fear and exclusion on Agatha can be found on her body which is full of metaphor that "human body is occupied mechanically". Although Agatha did not act in terror, other human still can not help but fearing a hybrid that blurs the human body. They cannot classify Agatha as a machine, but they cannot fully admit her human identity, either. Namely, Agatha's problematic digital-transformed body is objectified as a non-human but non-machine other in the gaze of spectator, while the body evokes the viewer's fear imagination of the ambiguity of the human body - that is, the underlying threat that the viewer's body could become non-human.

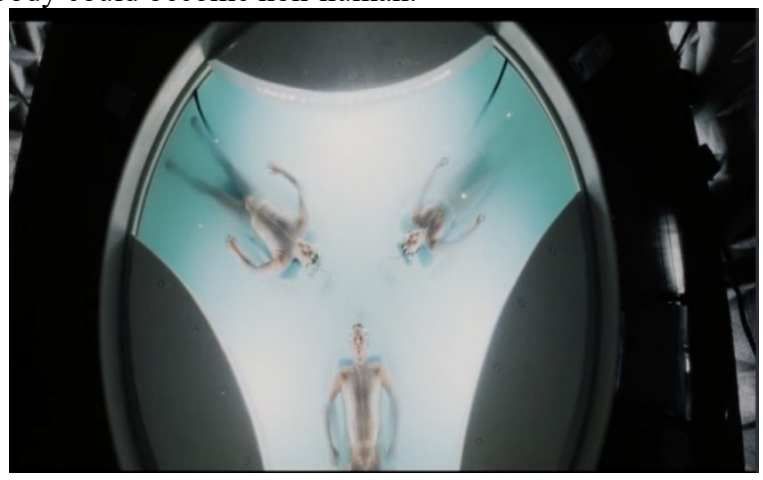

Figure 1 Precog body in Minority Report.

In Artificial Intelligence, digital technique created another binary human-machine model contrast to Agatha's body, as shown in fig2. David, the robot boy was designed as a highly simulated cyborg, whose appearance can confuse falsehood with reality, and the purpose of this design is to use David as an alternative to comfort the bereaved parents. Like Agatha, David's body is thought to be a hybrid that blurs the boundaries between human and machine. The difference is that Agatha's body is a normal human body before undergoing transformation, while David's body is originally a machine. In David's case, a more complete cyborg body is composed of highly humanized appearance and internal precise mechanical structure. In the film, there are several confusing moments - people cannot decide how to perceive David's body, since they sometimes think of it as human, sometimes as machine, and constantly swing in this contradictory dilemma. For example, when Monica, David's human "mother" hesitated whether or not to adopt a robot as a replacement for her child, David's highly humanized appearance inveigle her into making a positive decision. In another disturbing scene, when David was about to be executed as a robot, a stronger emotion was aroused-When the audiences who had been enjoying watching the robot slaughter saw David's appearance, they immediately turned to attack the executioner and roared at him, "he's just a boy!" Here, David's situation is the opposite of Agatha's. digital technology makes a machine-based cyborg body closer to the human body, and even attributes humanity to David. Here, the boundary of body, such as appearance, skin, constitutes the symbol of humanity, while the inherence is regarded as irrelevant. Skin is related to gaze phenomenology; it is the boundary at which we begin to objectify each other, who we see as part of the reality[4]. The possibility of skin as materialization is a proof of reality. Manea's theory raises a more complicated question about digital technology, machinery and the human body: Would it be possible that highly simulated appearances make machines become human? At least, David is no longer seen just as a machine, because people unconsciously regard David's body as a human. Through digital mechanical technology, David's body and the way in which his body is perceived are significantly affected, resulting in new metaphors and affects - he no longer belongs to machine, but closer to a "human-machine". Back to the final shot of Minority Report, Agatha, who was finally freed from mechanical slavery, could only live in seclusion or be imprisoned. But, at least, Agatha's body is finally represented in a human way, and she lives in a human way, not as a non-human prophet in a way enslaved by mechanical technology. Ironically, Agatha, as a human, needs to be humanized, namely, she is a "humanized human". David, by contrast, was abandoned by his mother after repeatedly exhibiting non-human features (such as facial deformation caused by eating human food; or connecting his body to the phone when helping his mother answer the phone, etc.). In these scenes, David, as a machine once regarded as human, is once again ironically dehumanized. In other words, he become a "dehumanized non-human". 


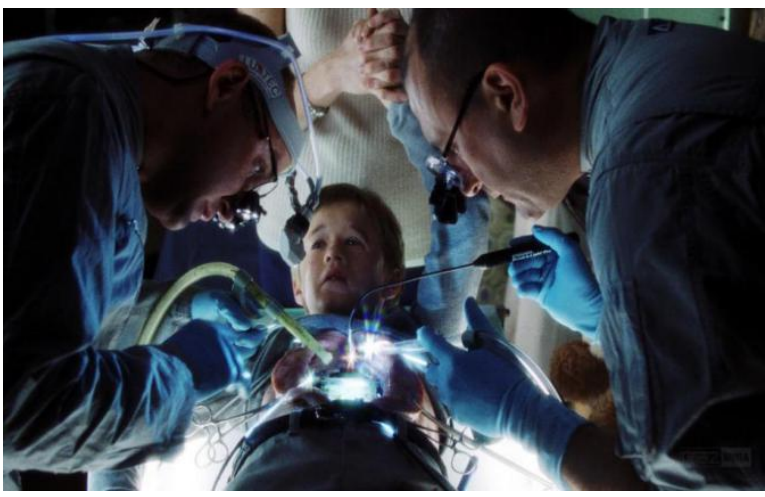

Figure 2 David's body in Artificial Intelligence.

\section{BEYOND DUALISM: BECOMING POST- HUMAN}

Comparatively, through the in-depth analysis to the body of Agatha and David, it can be found that digital mechanical technology can create two polarities of meanings in a posthumanist imagined future: Is human identity determined by external like skin and body or internal like gene and thought? Arguably, it is the paradoxical meanings that creates deeper uncertainty: identity is constructed by the body, however, it is also blurred by the body, thus creating a dreadful identity metaphor: people will be transformed into non-human, nonhuman can also be transformed into human. In other words, the human body and the machine are standing on the edge of each other, and the boundary between them is increasingly blurred. On top of that, a more profound debate has been triggered: how to explain whether the prototype of a cyborg body is a human or a machine? In general, cyborgs embody fears of the loss of those qualities that distinguish us from machines through their "obscene" visibility[5]. By visualizing the body of a semi machinery-human, these narratives emphasize what is lost - a sense of ego. The ethereal human subjectivity is confused and even eliminated by the materiality of the cyborg. These disturbing metaphors correspond to the above ontological problems. As Samantha Holland (2001) argues, obviously, "mind-body problem" is the core argument of cyborg film, and its narration tends to re-emphasize the "self" of spirit and Cartesian style in any materialistic self-concept[6]. Samantha's theory emphasizes memory and emotion and recalls Descartes' dualism of body and mind.

However, from this perspective, Agatha's human identity is highly challenged-her mind is almost empty and meaningless, because the only memory that Agatha as a precog has is the scene of her mother's death, and all other memories are predictions or flashbacks of other crime scenes. At this point, Agatha is indeed closer to a pictureproducing machinery than a human being; what is more, she has better machinery performance than ordinary machines, which makes her a super-machine. Here, cyborg is more mechanized than machines. David, by contrast, was created for merely one destiny: to love his mother. Namely, David's cognition and memory during his whole life are all about the human affect, "love". Even though he was betrayed and abandoned by his mother, David permanently fight for his humanity (love), which makes him a super-human. Here, contradictorily, cyborg is more humanized than human. Such a conclusion, in any sense, is contradictory.

But what if we turn to the other polarity and regard the body as the primary and ignore the mind? According to Habermas's claim (2003): Only when the body is perceived as "naturally growing" rather than "technologically made", can individuals think of themself as one with themselves and their body[7].

However, this theory will also slide to other paradoxes: if Agatha, originally as a human body, can be regarded as a person in ontology, then why is she still objectified and alienated by other human beings? Similarly, if David's body as an original machinery can only be seen as a machinery in ontology, then why does David become the only one in the film that keeps humanity and human memories? These arguments will continue, just as Bynum's (2001) reflexive asks: are we genes, bodies, brains, minds, experiences, memories or souls[8]? Here, arguments get into a dilemma, because the debates on the dualism of body and mind can never stop. We can't answer the question of whether body first or mind first. Therefore, the only way to answer cyborg's ontology is to break the debate of the duality of body and mind. In other words, the concern is not whether cyborg's ontology is body or mind, but the emergence of cyborg just breaks the binary prejudice between body and mind, and marks human entry into the post-human era - the combination of humanity. To interpret this, with a quote borrowed from Friedrich Nietzsche(2019) that "Man is a rope stretched between the animal and the Superman" - or evolved to a new version - cyborg is a rope stretched between the human and the post-human[9].

\section{CONCLUSION}

It seems that the best way to answer the question of bodymind binary is to break the quandary. Thus, a better interpretation of cyborg body is to admit the blur or even the dispel of the boundary between human and machinery. In that sense, Human beings are no longer human beings, but " transforming post-human". At this point, there is a more reasonable interpretation of Agatha and David's body and identity: Agatha's body, once invaded by mechanical technology, deprives her possibility to become a human again, but also keeps her away from becoming a pure nonhuman. In the swing of permanent identity confusion, she is transforming into a post-human. But in the human world, she can only be constructed as "the other". Similarly, David has gained more and more humanity in the process of living as a human being - but in order to love and be loved, he has to repeatedly reject his own mechanical body, which is the curse of mechanical technology that he will never get rid of. In the permanent struggle, David, as a humanized machine, has infinite affinity with human beings, but is finally abandoned by human world. In a nutshell, Artificial Intelligence and Minority Report respectively tell the story that human or machine becomes post-human. The post- 
humanist subject is a mixture, a hybrid of heterogeneous ingredients and a corporeal digital entity whose boundary has been continuously constructed and reconstructed[10]. That is to say, post-humanist identity is an identity being constructed, a becoming state, which means neither it belongs to the human category nor the non-human category. Post-human has not become a novel identity, but a rupture of the original fixed human identity under the background of digital technology increasingly penetrating into reality. Finally, the proposition of post-human is not limited in body or mind consultation, but also extends to more ethical issues. For example, if post-human is another kind of human, should they enjoy the human rights? Should human obligations be fulfilled? The acceptance of an identity must be accompanied by the rights and obligations associated with that identity. Or it can be said that it is the rightness and obligation of identities that determine who they are and how others should look at them and accept them. This paper has not made a further discussion on the ethical issues in the perspective of post-humanism, while it intends to provide a reference for the scholars who study post-human ethics.

\section{ACKNOWLEDGMENT}

First and foremost, I would like to show my deepest gratitude to my tutors and professors in my university, who have provided me with valuable guidance in every stage of the writing of this thesis. Further, I would like to thank all my friends and classmates, with whom I discussed and argued a lot about my topic. Without all their enlightening instruction and impressive kindness, I could not have completed my thesis.

\section{REFERENCES}

[1] M. Hauskeller, T. D. Philbeck, C. D. Carbonell. The Palgrave handbook of posthumanism in film and television. Houndmills, Basingstoke, Hampshire: Palgrave Macmillan, 2015.

[2] R. O. Thomas. Terminated: The Life and Death of the Cyborg in Film and Television. The Palgrave Handbook of Posthumanism in Film and Television, 2015, 57-65. doi: 10.1057/9781137430328_7

[3] D. Ayers. Chimeras and Hybrids: The Digital Swarms of the Posthuman Image. The Palgrave Handbook of Posthumanism in Film and Television, 2015, 99-108. doi: 10.1057/9781137430328_11

[4] T. Manea (n.d.). Our Posthuman Skin Condition. The Palgrave Handbook of Posthumanism in Film and Television. 2015, doi: 10.1057/9781137430328.0038

[5] T. Elsaesser, M. Hagener. Film theory: an introduction through the senses. New York: Routledge, 2015.

[6] M. Featherstone. Cyberspace/cyberbodies/cyberpunk: cultures of technological embodiment. London: SAGE, 2000.

[7] K. Baynes. Habermas. London: Routledge, 2016.

[8] B. Lunceford. The Ghost in the Machine: Humanity and the Problem of Self-Aware Information. The Palgrave Handbook of Posthumanism in Film and Television, 2015, 371-379. doi: $10.1057 / 9781137430328 \_37$

[9] F. Nietzsche. Thus Spake Zarathustra. Place of publication not identified: ARCTURUS, 2019.

[10] N. K. Hayles. How we became posthuman: virtual bodies in cybernetics, literature and informatics. Chicago: Univ. of Chicago Press, 2010. 